


\section{Glasilo Future}

\section{Stručno-znanstveni časopis}

Nakladnik:

FUTURA

\section{FuTUR}

Sjedište udruge: Šibenik
Adresa uredništva:

Bana Josipa Jelačića 13 a, 22000 Šibenik, Hrvatska / Croatia

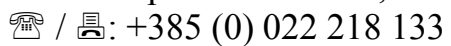

凶: urednistvo@gazette-future.eu / editors@gazette-future.eu

(3): www.gazette-future.eu

Uređivački odbor / Editorial Board:

Doc. dr. sc. Boris Dorbić, v. pred. - glavni i odgovorni urednik / Editor-in-Chief

Emilija Friganović, dipl. ing. preh. teh., v. pred. - zamjenica g. i o. urednika / Deputy Editor-in-Chief

Ančica Sečan Matijaščić, mag. act. soc. - tehnička urednica / Technical Editor

Antonia Dorbić, mag. art. - zamjenica tehničke urednice / Deputy Technical Editor

Prof. dr. sc. Željko Španjol

Mr. sc. Milivoj Blažević

Vesna Štibrić, dipl. ing. preh. teh.

Međunarodno uredništvo / International Editorial Board:

Prof. dr. sc. Kiril Bahcevandziev - Portugal (Instituto Politécnico de Coimbra)

Prof. dr. sc. Martin Bobinac - Srbija (Šumarski fakultet Beograd)

Prof. dr. sc. Zvezda Bogevska - Sjeverna Makedonija (Fakultet za zemjodelski nauki i hrana Skopje)

Dario Bognolo, mag. ing. - Hrvatska (Veleučilište u Rijeci)

Prof. dr. sc. Agata Cieszewska - Poljska (Szkoła Główna Gospodarstwa Wiejskiego w Warszawie)

Dr. sc. Bogdan Cvjetković, prof. emeritus - Hrvatska (Agronomski fakultet Zagreb)

Prof. dr. sc. Duška Ćurić - Hrvatska (Prehrambeno-biotehnološki fakultet Zagreb)

Prof. dr. sc. Margarita Davitkovska - Sjeverna Makedonija (Fakultet za zemjodelski nauki i hrana Skopje)

Prof. dr. sc. Dubravka Dujmović Purgar - Hrvatska (Agronomski fakultet Zagreb)

Prof. dr. sc. Josipa Giljanović - Republika Hrvatska (Kemijsko-tehnološki fakultet u Splitu)

Prof. dr. sc. Semina Hadžiabulić - Bosna i Hercegovina (Agromediteranski fakultet Mostar)

Prof. dr. sc. Péter Honfi - Mađarska (Faculty of Horticultural Science Budapest)

Prof. dr. sc. Valeria Ivanova - Bugarska (Fakultet za lozaro - gradinarstvo Plovdiv)

Prof. dr. sc. Mladen Ivić - Bosna i Hercegovina (Univerzitet PIM)

Doc. dr. sc. Orhan Jašić - Bosna i Hercegovina (Filozofski fakultet Tuzla)

Prof. dr. sc. Tajana Krička - Hrvatska (Agronomski fakultet Zagreb)

Doc. dr. sc. Dejan Kojić - Bosna i Hercegovina (Univerzitet PIM)

Slobodan Kulić, mag. iur. - Srbija (Srpska ornitološka federacija i Confederation ornitologique mondiale)

Prof. dr. sc. Biljana Lazović - Crna Gora (Biotehnički fakultet Podgorica)

Doc. dr. sc. Zvonimir Marijanović - Republika Hrvatska (Kemijsko-tehnološki fakultet u Splitu)

Doc. dr. sc. Ana Matin - Hrvatska (Agronomski fakultet Zagreb)

Prof. dr. sc. Bosiljka Mustać - Hrvatska (Sveučilište u Zadru)

Hrv. akademik prof. dr. sc. Stanislav Nakić - Bosna i Hercegovina (Sveučilište Hercegovina Mostar)

Sandra Popović, mag. ing. - Srbija (Poljoprivredni fakultet Beograd)

Doc. dr. sc. Bojan Simovski - Sjeverna Makedonija (Šumarski fakultet Skopje)

Prof. dr. sc. Davor Skejić - Hrvatska (Građevinski fakultet Zagreb)

Doc. dr. sc. Milan Stanković - Srbija (Univerzitet u Kragujevcu)

Akademik prof. dr. sc. Refik Šećibović - Bosna i Hercegovina (Visoka škola za turizam i menadžment Konjic)

Prof. dr. sc. Andrej Šušek - Slovenija (Fakulteta za kmetijstvo in biosistemske vede Maribor)

Prof. dr. sc. Elma Temim - Bosna i Hercegovina (Agromediteranski fakultet Mostar)

Mr. sc. Merima Toromanović - Bosna i Hercegovina (Biotehnički fakultet Univerziteta u Bihaću)

Doc. dr. sc. Ivana Vitasović Kosić - Hrvatska (Agronomski fakultet Zagreb)

Doc. dr. sc. Ana Vujošević - Srbija (Poljoprivredni fakultet Beograd)

Prof. dr. sc. Vesna Židovec - Hrvatska (Agronomski fakultet Zagreb)

Lektura i grafička priprema: Ančica Sečan Matijaščić, mag. act. soc.

Objavljeno: 30. lipnja 2019. godine.

Časopis izlazi u elektroničkom izdanju dva puta godišnje, krajem lipnja i prosinca, a predviđena su i dva interdisciplinarna specijalna izdanja tijekom godine iz STEM i ostalih znanstvenih/umjetničkih područja.

Časopis je besplatan. Rukopisi i recenzije se ne vraćaju i ne honoriraju.

Umnožavanje (reproduciranje), stavljanje u promet (distribuiranje), priopćavanje javnosti, stavljanje na raspolaganje javnosti odnosno prerada u bilo kojem obliku nije dopuštena bez pismenog dopuštenja Nakladnika.

Sadržaj objavljen u Glasilu Future može se slobodno koristiti u osobne i obrazovne svrhe uz obvezno navođenje izvora. 


\section{Glasilo Future}

\section{Stručno-znanstveni časopis}

FUTURA - stručno-znanstvena udruga za promicanje održivog razvoja, kulture i međunarodne suradnje, Bana Josipa Jelačića 13 a, 22000 Šibenik, Hrvatska

(2019) $2(1-2) 01-76$

\section{SADRŽAJ:}

\section{Izvorni znanstveni rad (original scientific paper)}

Anarma Poprženović, Špela Pezdevšek Malovrh, B. Dorbić, E. Delić

Stavovi o društvenoj funkciji i općem stanju zelenila u Bihaću (Bosna i Hercegovina)

Attitudes on social function and overall status of greenery in the city of Bihać (Bosnia and

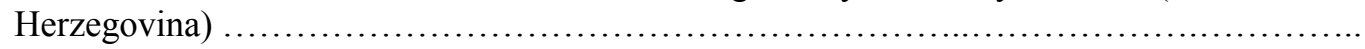

Aida Šukalić, Alma Rahimić, Vedrana Komlen, Alma Mičijević, Lamija Aliman

Sadržaj arsena u plodovima nektarine (Prunus persica var. nucipersica Schnied.) na području Hercegovine s procjenom rizika na zdravlje ljudi

The content of arsenic in nectarine fruit (Prunus persica var. nucipersica Schnied.) with risk assessment for human health on area of Herzegovina

Emilija Friganović, Martina Runje, Sara Ujaković, B. Dorbić, Mladenka Šarolić,

Duška Ćurić, Tajana Krička

Senzorska procjena tjestenine obogaćene proteinima konoplje i graška

Sensory evaluation of hemp and pea proteins enriched pasta

\section{Prethodno priopćenje (preliminary communication)}

B. Dorbić, Emilija Friganović, Marija Slipčević, Margarita Davitkovska, Zvezda Bogevska, Ana Vujošević

Senzorska procjena različitih oparaka od aromatičnog bilja

Sensory evaluation of different infusions from aromatic herbs

\section{Stručni rad (professional paper)}

Mladenka Šarolić, Josip Roguljić, Emilija Friganović, Žana Delić, Boris Dorbić, Marina

\section{Torić}

Poljički soparnik

"Poljički soparnik".

\section{Nekategorizirani rad (uncategorised paper)}

\section{S. Kulić}

Kanarinac pjesme slavujar (Song Canary "Slavujar")

Popularan rad

Popular paper

Zdenka Bilušić

Prikaz konferencije

Review of conference

\section{B. Dorbić}

Društvene vijesti i obavijesti

Social news and announcements 
Anarma Poprženović, Špela Pezdevšek Malovrh, B. Dorbić, E. Delić / Stavovi o društvenoj funkciji i općem stanju zelenila u Bihaću (Bosna i Hercegovina) / Glasilo Future (2019) 2 (1-2) 01-14

\title{
Stavovi o društvenoj funkciji i općem stanju zelenila u Bihaću (Bosna i Hercegovina)
}

\section{Attitudes on social function and overall status of greenery in the city of Bihać}

(Bosnia and Herzegovina)

\author{
Anarma Poprženović ${ }^{1}$, Špela Pezdevšek Malovrh Boris Dorbić $^{3}$, Emir Delić $^{4}$ \\ izvorni znanstveni rad (original scientific paper)
}

doi: $10.32779 /$ gf.2.1-2.1

\section{Sažetak}

Drveće i grmlje u sustavu gradskog zelenila ima niz različitih uloga: funkcionalnih, estetskih, društvenih, ekoloških i gospodarskih te su značajni element svakog grada. Prema podacima o bilansu namjene $\mathrm{u}$ obuhvatu Urbanističkog plana grada Bihaća, planirane i postojeće zelene površine zauzimaju oko 553 ha urbanog područja. Cilj rada je bio analiza i istraživanje stavova o društvenoj funkciji i općem stanju zelenila u Bihaću. Anketno istraživanje je provedeno tijekom mjeseca siječnja 2018. godine na različitim lokacijama grada Bihaća.

Rezultati istraživanja su pokazali da je ispitanicima Gradski park najomiljenija zelena površina. Preferiraju povećanje zelenih površina u gradu i daju na značaju edukaciji građana o važnosti istih. Smatraju da bi održavanje zelenila Gradskog parka trebali obavljati i građani. Posebno su istaknuli problem loše osvijetljenosti u navedenom parku, kao i nedostatak klupa te koševa za smeće, pojavu vandalizama itd.

Ključne riječi: zelenilo, stanje, društvena funkcija, stavovi, Bihać
Abstract
Trees and shrubs in urban greenery play a wide range of roles: functional, aesthetic, social, ecological and economic and are considered an important feature of every city. In accordance with the data in the official records on areas included in Urban Development Plan of the city of Bihać, both the planned and existing green spaces account for around 553 hectares of urban land. The specific objective of the paper is an attitudinal research on social function and overall status of greenery and the City Park in Bihać. The survey research was conducted in January 2018 on the territory of the City of Bihać.

\footnotetext{
${ }^{1}$ Anarma Poprženović, 77000 Bihać, Bosna i Hercegovina.

* E-mail: anarma_poprzenovic@outlook.com.

${ }^{2}$ Biotehniška fakulteta, Univerza v Ljubljani, Oddelek za gozdarstvo, Jamnikarjeva ulica 101, 1000 Ljubljana, Republika Slovenija.

${ }^{3}$ Veleučilište "Marko Marulić" u Kninu, Odjel Poljoprivreda krša, Krešimirova 30, 22300 Knin, Republika Hrvatska.

${ }^{4}$ Slavne Brigade 71, 77000 Bihać, Bosna i Hercegovina.
} 
Anarma Poprženović, Špela Pezdevšek Malovrh, B. Dorbić, E. Delić / Stavovi o društvenoj funkciji i općem stanju zelenila u Bihaću (Bosna i Hercegovina) / Glasilo Future (2019) 2 (1-2) 01-14

According to research findings, the respondents pointed out the City Park as their favourite green space. They advocate the increase in green spaces in the City and they point out the need to raise the awareness of the general public about the importance of green spaces. They believe that the citizens also need to be involved in the maintenance of the greenery in the City Park. The problem of poor lighting in the park in question was primarily emphasised, as well as a lack of park benches and litter bins and the onset of vandalism.

Key words: greenery, state, social function, attitudes, Bihać.

\section{Uvod}

Drveće pruža mnoge koristi, a ima i tržišnu vrijednost zbog svojih različitih uloga: funkcionalnih, estetskih, društvenih, ekoloških i gospodarskih (Purcell, 2012). Pojam urbanih šuma u širem smislu odnosi se na pojedinačno drveće, drvorede, parkove i šume. Iako ne postoji istoznačna definicija urbanih šuma, zajednička im je karakteristika prisutnost drveća. U Europi koncept urbanog šumarstva posebno dolazi do izražaja zadnjih 20-ak godina (Konijnendijk, 2003).

Tyrväinen razlikuje pet skupina koristi od urbanih šuma: društvene (rekreacija, poboljšanje čovjekovog okoliša, utjecaj na fizičko i psihičko zdravlje čovjeka, kulturne i povijesne vrijednosti), estetske i arhitektonske koristi (bioraznolikost, doživljaj prirode), klimatske i arhitektonske koristi (pružanje zasjene (hlada), smanjenje utjecaja vjetra, smanjenje temperaturnih razlika, utjecaj na zračnu vlagu, smanjenje zračnog zagađenja, smanjenje buke, smanjenje refleksije u prostoru, utjecaj na regulaciju poplava, smanjenje erozije tla), ekološke koristi (stanište za floru i faunu), ekonomske koristi (npr. drvo, gljive i slično; utjecaj na vrijednost imovine, turizam itd.) (Tyrväinen et al., 2005, prema Tyrväinen, 1999).

Urbani zeleni prostori su značajni element svakog grada, dio su sveukupne slike grada, povećavaju bio raznolikost i u načelu su strukturni i funkcionalni elementi koji čine gradove i urbana područja pogodnijim za stanovanje.

Da parkovi i zelene površine imaju značajnu društvenu ulogu u urbanim sredinama može se pronaći i u sličnim istraživanjima (Vitasović Kosić i Aničić, 2005; Stanić i Buzov, 2014; Dorbić i Temim, 2014). koja su provedena na području Republike Hrvatske.

Urbano zelenilo predstavlja značajan element urbanog standarda stanovnika. Kroz izradu Urbanističkog plana grada Bihaća za razdoblje 2010. - 2030. godine, urbano zelenilo je definirano kao javne zelene površine, parkovi, zone sporta i rekreacije i zaštitno zelenilo. Prema bilanci namjene površina u obuhvatu Urbanističkog plana grada Bihaća zelene površine (planirane i postojeće) zauzimaju oko 553 ha urbanog područja grada od čega 3,1 ha se odnosi na Gradski park. Održavanje javnog zelenila se obavlja u skladu s odredbama Odluke o komunalnom redu i Zakona o komunalnim djelatnostima USK-a (Strategija razvoja općine Bihać, 2014 - 2023). 
Anarma Poprženović, Špela Pezdevšek Malovrh, B. Dorbić, E. Delić / Stavovi o društvenoj funkciji i općem stanju zelenila u Bihaću (Bosna i Hercegovina) / Glasilo Future (2019) 2 (1-2) 01-14

Gradski park ima iznimno važnu urbanističku, estetsku, ekološku te društvenu ulogu u gradu Bihaću te će se i jedan dio istraživanja u ovom radu odnositi na njega. Značajan je za građane i posjetitelje, djecu i odrasle, u pogledu rekreacije te kulturne vrijednosti.

Povijest nastanka i prvobitni izgled Gradskog parka treba biti predmet detaljnijeg istraživanja kako bi se dobila točna slika o vrijednosti ovog prostora. Na temelju toga bi park učvrstio poseban status u urbanoj povijesti i izgradnji identiteta grada Bihaća (Natura Jadera, 2014, prema Delić et al., 2018).

Površina Gradskog parka iznosi 3,1 ha. Park po obliku, izgledu, biljnim svojtama i vrijednosti najznačajnija i najvrjednija javna zelena površina u gradu Bihaću. Kako je prethodno navedeno, jedan je od ljepših parkova u Bosni i Hercegovini, a izgrađen je za vrijeme austrougarske uprave 1888. godine (Delić et al., 2018).

Cilj rada je bilo istraživanje stavova o društvenoj funkciji i općem stanju zelenila u Bihaću.

\section{Materijali i metode}

Anketno istraživanje je provedeno u cilju analize društvenih gledišta na opće stanje zelenila u Gradu Bihaću (Slike 1. i 2). Društveni aspekti su u ovim istraživanju operacionalizirani kao: a) sociodemografske karakteristike ispitanika; b) zadovoljstvo i problemi vezani za zelenilo i na c) percepciju o općem stanju zelenila Bihaća. Istraživanje je bilo kvantitativnog tipa i provedeno je putem anketnog upitnika. Uzorak je činilo 50 ispitanika s područja grada Bihaća. Ovo istraživanje ima preliminarni karakter i može poslužiti kao osnova za potencijalna buduća istraživanja iz slične tematike.

Sociodemografski podaci pokazuju da je u navedenom istraživanju bilo uključeno 24 muškarca i 26 žena. Starosna struktura uzorka bila je sljedeća: 18 - 30 godina (50 \%), 31 - 40 godina (22\%), $41-50$ godina (12\%), 51 - 60 godina $(8 \%), 61-70$ godina $(8 \%)$, a izbor ispitanika je bio slučajan. U pogledu stupnja obrazovanja struktura uzorka je bila: srednja stručna sprema (55 \%) i fakultetsko obrazovanje (48\%) ispitanika.

$\mathrm{Za}$ potrebe prikupljanja podataka tijekom anketnog istraživanja izrađen je upitnik s pitanjima sastavljenim od tri dijela. Prvi i drugi dio anketnog upitnika se sastojao od pitanja koja su se odnosila na stavove o općem stanju i posjećenosti zelenila Bihaća, dok je treći dio obuhvaćao stavove o posjećenosti, značaju te o problemima zelenila Gradskog parka u Bihaću.

Anketno istraživanje je provedeno tijekom mjeseca siječnja 2018. godine na području grada Bihaća. Za obradu podataka, njihovu analizu i prezentaciju korišteni su standardni programski paketi Ms Office (Microsoft Excel) i statistički program SPSS (verzija 24). Korištena je metoda frekvencijske analize koja je poslužila za prikazivanje distribucije odgovora na postavljena pitanja u upitniku (udio, 
Anarma Poprženović, Špela Pezdevšek Malovrh, B. Dorbić, E. Delić / Stavovi o društvenoj funkciji i općem stanju zelenila u Bihaću (Bosna i Hercegovina) / Glasilo Future (2019) 2 (1-2) 01-14

prosjek) te mjerila centralne tendencije (izračun aritmetičke sredine i za tu svrhu je korištena Likertova ljestvica od 1-5), gdje 1 znači "ne slažem se u potpunosti", 2 "slažem se u zadovoljavajućoj mjeri, 3. "osrednje slaganje, 4. "veoma se slažem" i 5. "slažem se u potpunosti".

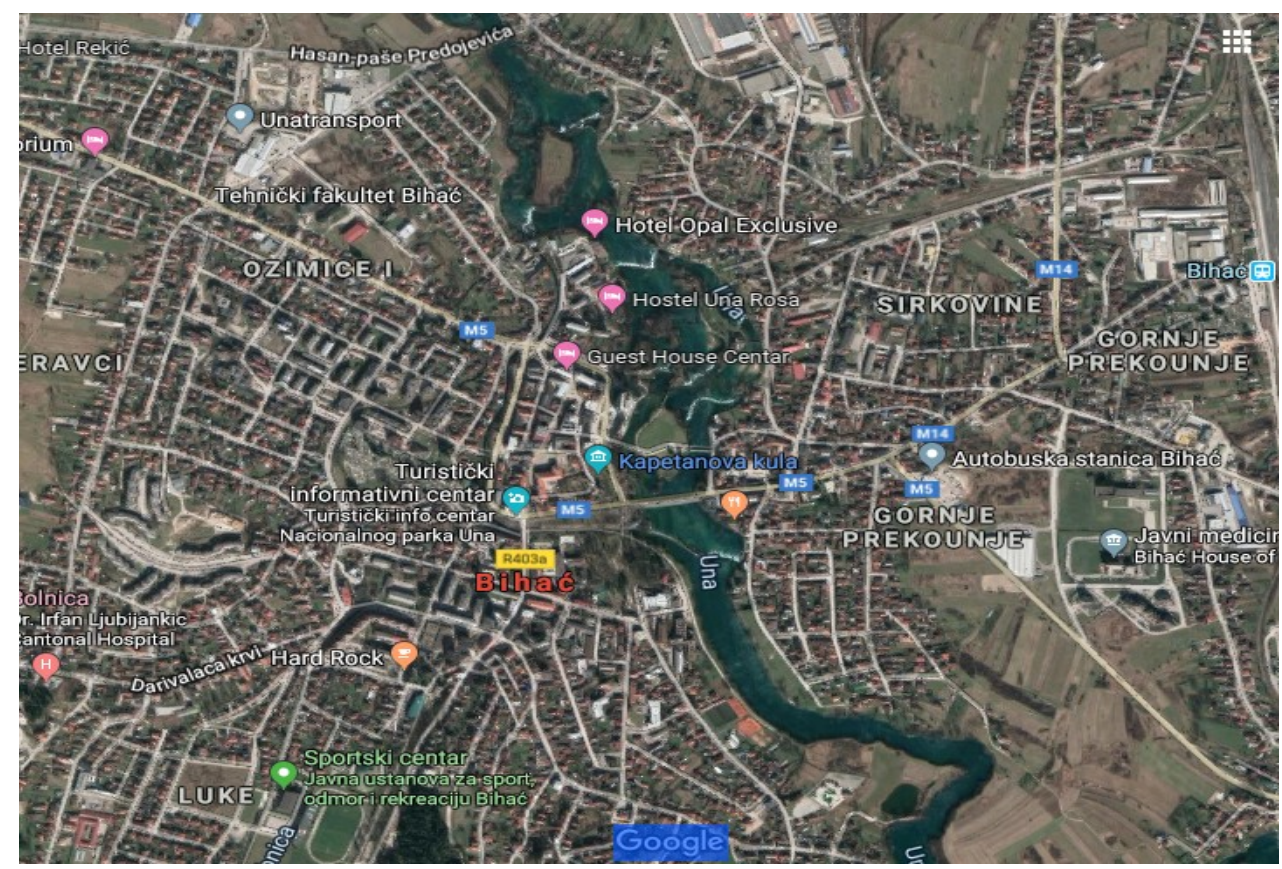

Slika 1. Satelitski snimak grada Bihaća (Google Earth).

Figure 1. Satellite image of the town of Bihac (Google Earth).

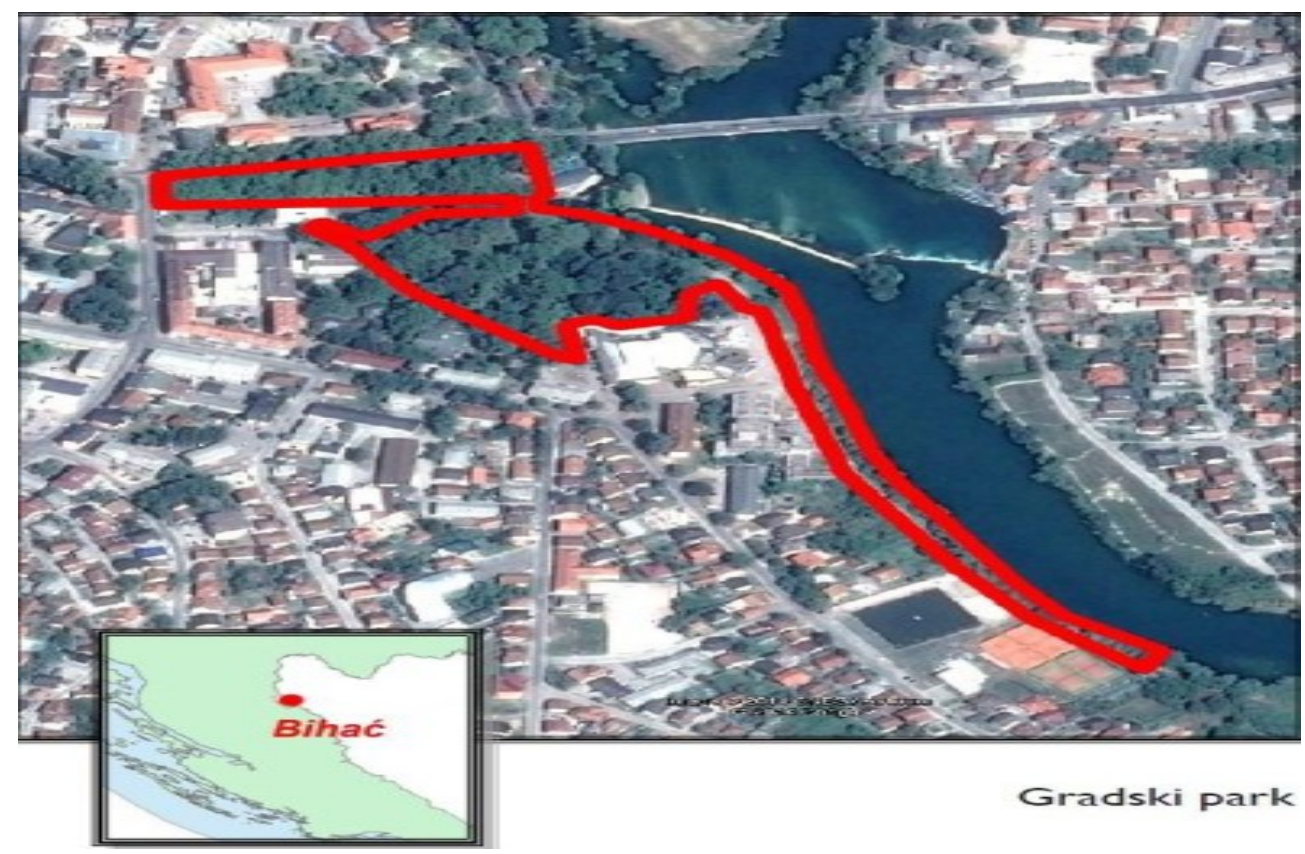

Slika 2. Satelitski snimak Gradskog parka u Bihaću (označeno crvenim) (Natura Jadera, 2014, prema Delić et al., 2018).

Figure 2. Satellite image of the City Park in Bihać (marked red) (Natura Jadera, 2014, prema Delić et al., 2018). 
Anarma Poprženović, Špela Pezdevšek Malovrh, B. Dorbić, E. Delić / Stavovi o društvenoj funkciji i općem stanju zelenila u Bihaću (Bosna i Hercegovina) / Glasilo Future (2019) 2 (1-2) 01-14

\section{Rezultati i diskusija}

\section{Analiza općeg stanja zelenila Bihaća}

Prva skupina pitanja je sadržavala šest pitanja koja su se odnosila na opće stanje zelenila Bihaća i edukaciji o važnosti istog (Tablica 1).

Tablica 1. Stavovi o općem stanju zelenila Bihaća (prema Poprženović, 2018).

Table 1. Attitudes about the general state of Bihać greenery (according to Poprženović, 2018).

\begin{tabular}{|l|l|l|l|}
\hline R. br. & Pitanja & Ponuđeni odgovori & Odgovori (\%) \\
\hline 1. & $\begin{array}{l}\text { Koje su vam najomiljenije zelene } \\
\text { površine u gradu Bihaću }\end{array}$ & $\begin{array}{l}\text { a) Aleje } \\
\text { b) Gradski park } \\
\text { c) Zeleni otoci }\end{array}$ & a) 28 \\
& & a) 66 \\
c) 6
\end{tabular}

- Na prvo pitanje (Tablica 1.) koje se odnosilo na koju urbanu zelenu površinu građani Bihaća najviše preferiraju s dvije trećine odgovora vidljivo prednjači Gradski park, zatim "aleje" (jedna trećina ispitanika) i najmanje zelene otoke.

- Percipirajući tvrdnju "Bihać je zeleni grad" na ljestvici od 1 do 5 (gdje 1 znači "ne slažem se u potpunosti", a 5 "slažem se u potpunosti") ispitanici su potonje ocijenili s ocjenom 4,32, 
Anarma Poprženović, Špela Pezdevšek Malovrh, B. Dorbić, E. Delić / Stavovi o društvenoj funkciji i općem stanju zelenila u Bihaću (Bosna i Hercegovina) / Glasilo Future (2019) 2 (1-2) 01-14

odnosno izrazito se slažu s postavljenom. Polovina ispitanika se u potpunosti slaže s navedenom tvrdnjom, dok se približno jedna trećina izrazito slaže s navedenim. Seferagić (1988), tako npr. za istraživanja provedena u Zagrebu tijekom 80-ih godina 20. stoljeća navodi da opremljenost naselja ne zadovoljava svakodnevne potrebe stanovnika te da stanovnici takva naselja percipiraju kao monotona i uniformna s malo zelenila i nejasno organizirana.

- Na tvrdnju "Količina zelenih površina se neprestano smanjuje", oko polovice ispitanika se slaže u potpunosti s navedenom tvrdnjom, četvrtina ih se izrazito slaže, a manji dio ispitanika je neutralnog stava. Dalje, neslaganje s tom tvrdnjom izrazilo je nešto više od desetine ispitanika i to da se izrazito ne slaže. Navedenoj tvrdnji je dodijeljena ocjena 3,94, veoma se slažu s navedenom tvrdnjom.

- Na tezu da je potrebno povećati količinu zelenih površina u Gradu Bihaću u potpunosti se slaže velika većina ispitanika.

Ispitanici u potpunosti smatraju (ocjena 4,72) da je potrebno povećati količinu zelenih površina $u$ Bihaću (Slike 3., 4., 5. i 6.).

- O značaju edukacije građana o važnosti zelenih površina u gradovima ispitanici su u prosjeku dodijelili iznimno visoku ocjenu (4.92), tj. smatraju da je iznimno važno educirati građane o navedenom. Od toga velika većina ispitanika se u potpunosti slaže s navedenim.

- Na tvrdnju da bi djecu od vrtićke dobi trebalo educirati o važnosti zelenih površina u gradovima ispitanici su se u većoj mjeri u potpunosti složili s navedenom tvrdnjom. Prema nekim inozemnim istraživanjima (Kaplan i Kaplan, 1989) mladi preferiraju divljinu (šume s više zelenila), dok odrasli i djeca više odabiru pregledne šume za relaksaciju. Djeca vole prirodnije izgrađene prostore za igru i zabavu od kvalitetno organiziranih i planiranih igrališta.

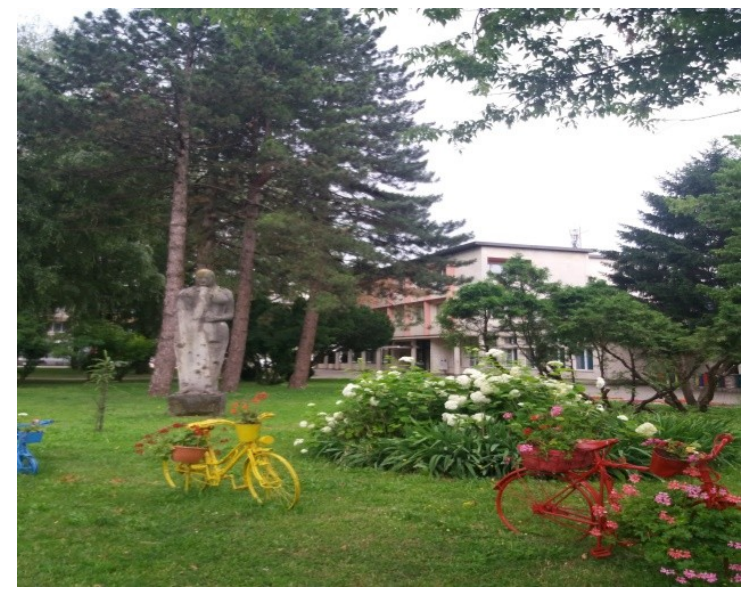

Slika 3. Jedna gradska zelena površina u Bihaću (Foto: B. Dorbić, 2018).

Figure 3. One green urban area in Bihać (Photo: B. Dorbić, 2018).

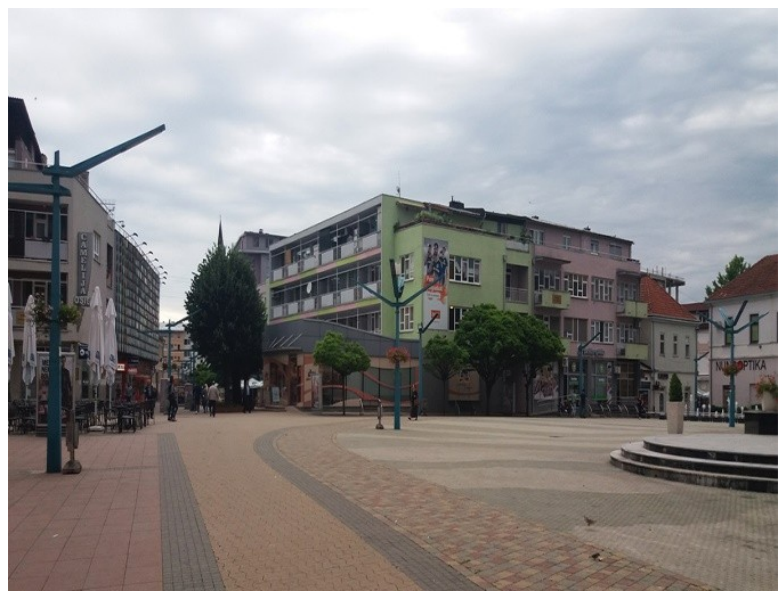

Slika 4. Zelenilo u centralnom dijelu Bihaća (Foto: B. Dorbić, 2018).

Figure 4. Greenery in the central part of Bihać (Photo: B. Dorbić, 2018). 


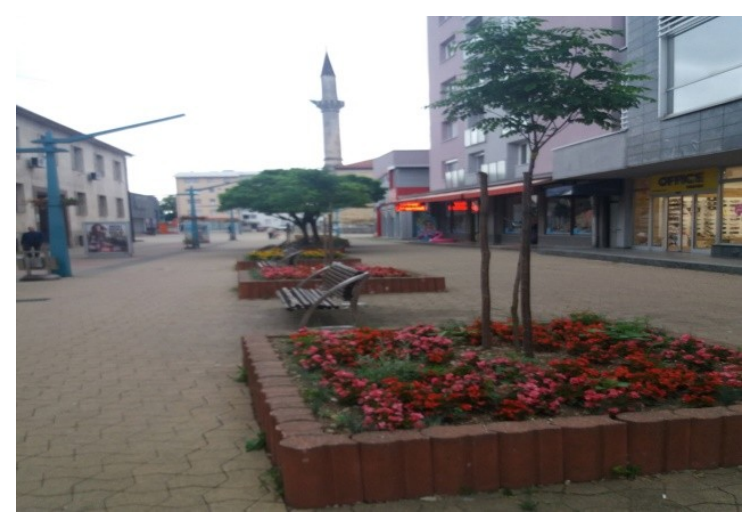

Slika 5. Cvjetne gredice u centru Bihaća Situacija - 1 (Foto: B. Dorbić, 2018).

Figure 5. Flower bed in the center of BihacSituation-1 (Photo: B. Dorbić, 2018).

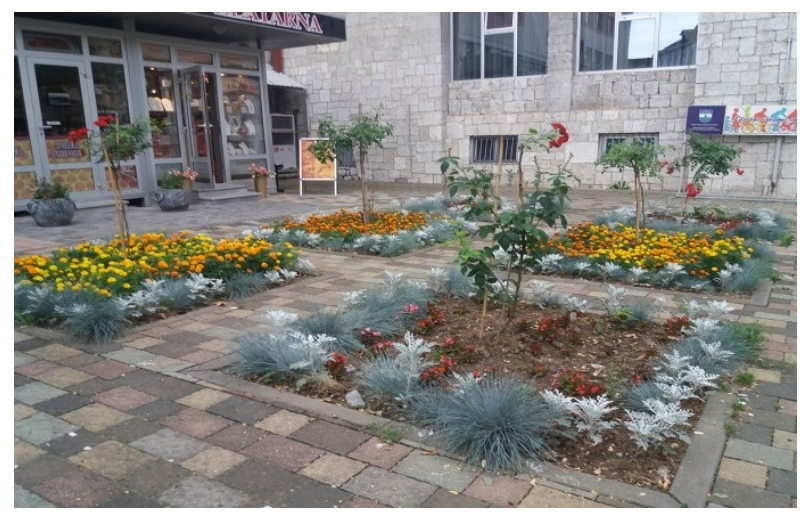

Slika 6. Cvjetne gredice u centru Bihaća Situacija-2 (Photo: B. Dorbić, 2018).

Figure 6. Flower bed in the center of BihacSituation - 2 (Photo: B. Dorbić, 2018).

\section{Analiza stavova o posjećenosti i značaju zelenila Gradskog parka u Bihaću}

Bihaćki Gradski park koji se više od jednog stoljeća nalazi u samom centu Bihaća jedna je od glavnih zelenih gradskih oaza. Ovaj dio anketnog upitnika odnosio se na zelenilo Gradskog parka u Bihaću. Pitanja su se odnosila na posjećenost Gradskog parka i važnost zelenila Gradskog parka u Bihaću (Tablica 2).

Tablica 2. Stavovi o posjećenosti i značaju zelenila Gradskog parka u Bihaću (prema Poprženović, 2018).

Table 2. Attitudes about the attendance and importance of the greenery of the City Park in Bihać (according to Poprženović, 2018).

\begin{tabular}{|l|l|l|l|}
\hline R. br. & Pitanja & Ponuđeni odgovori & Odgovori (\%) \\
\hline 1. & $\begin{array}{l}\text { Koliko često posjećujete Gradski } \\
\text { park? }\end{array}$ & $\begin{array}{l}\text { a) Nekoliko puta tjedno } \\
\text { b) Jednom tjedno } \\
\text { c) Rjeđe od jednom tjedno } \\
\text { d) Nikada }\end{array}$ & $\begin{array}{l}\text { a) } 24 \\
\text { b) } 40 \\
\text { c) } 32 \\
\text { d) } 4\end{array}$ \\
\hline 2. & $\begin{array}{l}\text { Bi li sudjelovali u sadnji drveća } \\
\text { u Gradskom parku ukoliko bi } \\
\text { postojala ta mogućnost? }\end{array}$ & $\begin{array}{l}\text { a) Da } \\
\text { b) Ne }\end{array}$ & $\begin{array}{l}\text { a) } 96 \\
\text { b) } 4\end{array}$ \\
\hline 3. & $\begin{array}{l}\text { Tko bi trebao biti odgovoran za } \\
\text { održavanje zelenila Gradskog } \\
\text { parka u Bihaću? }\end{array}$ & $\begin{array}{l}\text { a) Gradsko komunalno poduzeće } \\
\text { b) Građani i Gradsko komunalno poduzeće }\end{array}$ & $\begin{array}{l}\text { a) } 20 \\
\text { b) } 80\end{array}$ \\
\hline 4. & $\begin{array}{l}\text { Koliko Vam je značajno zelenilo } \\
\text { Gradskog parka u Bihaću? }\end{array}$ & $\begin{array}{l}\text { a) Značajno } \\
\text { b) Izrazito značajno }\end{array}$ & $\begin{array}{l}\text { a) } 2 \\
\text { b) } 98\end{array}$ \\
\hline 5. & $\begin{array}{l}\text { Koliko se problem smeća odnosi } \\
\text { a) Izrazito se odnosi } \\
\text { na zelenilo Gradskog parka? } \\
\text { c) Niti se odnosi, niti se ne odnosi } \\
\text { d) Ne odnosi se }\end{array}$ & $\begin{array}{l}\text { a) } 46 \\
\text { b) } 41 \\
\text { c) } 4\end{array}$ \\
d) 9
\end{tabular}

- Na pitanje koliko često posjećuju Gradski park, skoro polovina ispitanika se izjasnila da ga posjećuju jednom tjedno, oko trećine rjeđe od jednom tjedno, četvrtina nekoliko puta tjedno, a nikad ga nije posjetilo $4 \%$ ispitanika (Tablica 2). Danas se uglavnom ovakvi tipovi parkova 
Anarma Poprženović, Špela Pezdevšek Malovrh, B. Dorbić, E. Delić / Stavovi o društvenoj funkciji i općem stanju zelenila u Bihaću (Bosna i Hercegovina) / Glasilo Future (2019) 2 (1-2) 01-14

koriste radi opuštanja i rekreacije, dok su prije (od 19 st.) građani dolazili u njih da bi bili viđeni (Vitasović Kosić i Aničić, 2005). Sukladno drugim literaturnim istraživanjima, kao npr. Čaldarović (1989), koji navodi da osobe starije životne dobi i mlađa djeca najviše posjećuju parkove.

- Većina ispitanika (96 \%) bi sudjelovala i u sadnji drveća u Gradskom parku ukoliko bi za to postajala mogućnost. U ovaj park bi bilo poželjno uvoditi elemente autentičnosti i prepoznatljivosti te autohtone ukrasne vrste. Navedeno je trend u ukrasnoj hortikulturi koji se već od konca 20. stoljeća preporuča i uglavnom u struci provodi (Dorbić et al., 2012; Vršek i Kurtela 1995; Židovec i Karlović, 2005).

- Na pitanje tko bi po mišljenju ispitanika trebao biti odgovoran za održavanje zelenila Gradskog parka, velika većina ispitanika je odgovorilo da bi tu dužnost trebali obavljati i građani i gradsko komunalno poduzeće. Dok petina ispitanika smatra da je za navedeno ipak odgovorno gradsko komunalno poduzeće. Dorbić et al., 2013, navode da su čistoća, uredno održavanje i oblikovan krajobraz uvjeti za razvoj elitnog turizma, kojem teži i grad Bihać na čijem se prostoru nalazi Nacionalni park Una i druge prirodne vrijednosti.

- Tijekom anketnog istraživanja $98 \%$ ispitanika se izjasnilo da im je osobno izrazito važno zelenilo Gradskog parka (Slike 7. i 8.).

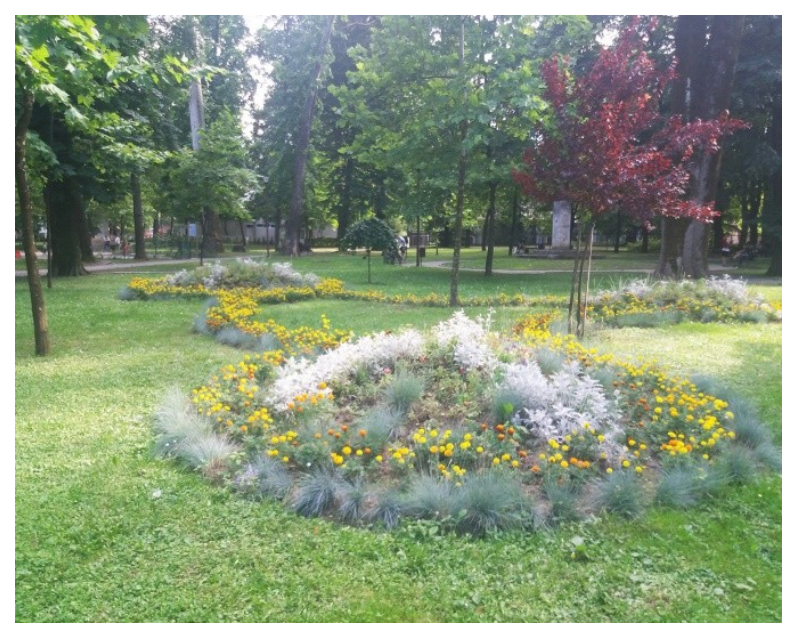

Slika 7. Pogled - 1. na Gradski park (Foto: E. Delić, 2018).

Figure 7. View - 1 at City park (Photo: E. Delić, 2018).

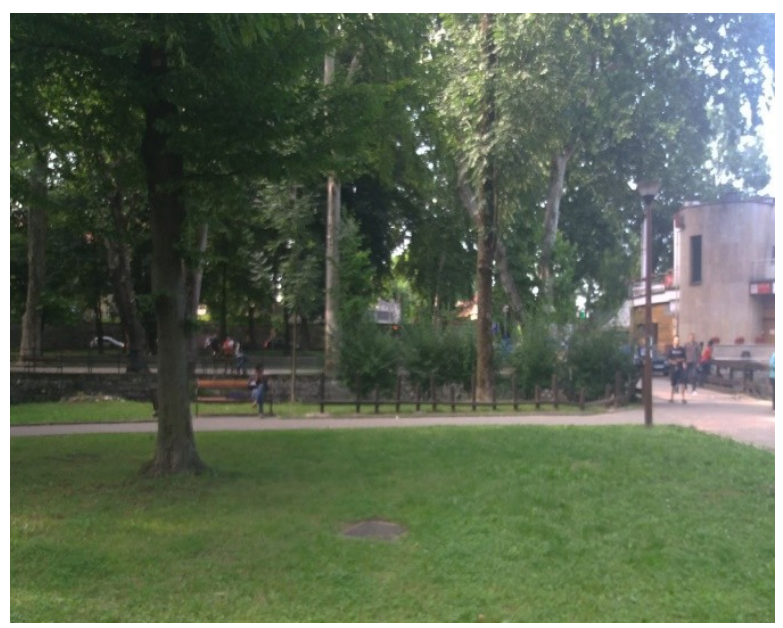

Slika 8. Pogled - 2. na Gradski park (Foto: E. Delić, 2018).

Figure 8. View - 2 at City park (Photo: E. Delic, 2018).

Pozitivne percepcije oko boravka u parkovima imaju i građani nekih hrvatskih gradova (Dorbić i Temim, 2014; Dorbić et al, 2013; Miškić-Domislić et al., 2013).

- Na pitanje "Koliko se problem smeća odnosi na zelenilo Gradskog parka?" nešto manje od polovice ispitanika je odgovorilo da se to izrazito odnosi, a da se odnosi $41 \%$. 
Anarma Poprženović, Špela Pezdevšek Malovrh, B. Dorbić, E. Delić / Stavovi o društvenoj funkciji i općem stanju zelenila u Bihaću (Bosna i Hercegovina) / Glasilo Future (2019) 2 (1-2) 01-14

Prema njihovom mišljenju i čistoća grada te gradskih parkova nije na visokom nivou. Slično navodi Turalija (2005) za Osijek te Dorbić i Temim (2014) za Šibenik. Ipak smo posljednjih nekoliko godina, za navedene hrvatske gradove uočili značajniji napredak po pitanju "čistoće grada" i održavanja zelenih površina.

\section{Analiza problema vezanih za zelenilo Gradskog parka u Bihaću}

U ovom dijelu anketnog istraživanja pitanja su se odnosila na postojanost problema vezanih za urbano zelenilo Gradskog parka u Bihaću (Tablica 3.).

Tablica 3. Stavovi o problemima vezanim za zelenilo Gradskog parka u Bihaću (prema Poprženović, 2018).

Table 3. Attidues on problems related to the greenery of the City Park in Bihać (according to, Poprženović, 2018).

\begin{tabular}{|c|c|c|c|}
\hline R. br. & Pitanja & Ponuđeni odgovori & $\begin{array}{l}\text { Odgovori } \\
(\%)\end{array}$ \\
\hline 1. & $\begin{array}{l}\text { Koliko se problem nedovoljne } \\
\text { osvjetljenosti odnosi na zelenilo } \\
\text { Gradskog parka? }\end{array}$ & $\begin{array}{l}\text { a) Izrazito se odnosi } \\
\text { b) Odnosi se } \\
\text { c) Niti se odnosi, niti se ne odnosi } \\
\text { d) Ne odnosi se }\end{array}$ & $\begin{array}{l}\text { a) } 65 \\
\text { b) } 20 \\
\text { c) } 9 \\
\text { d) } 7\end{array}$ \\
\hline 2. & $\begin{array}{l}\text { Koliko se problem nedostatka klupa } \\
\text { za sjedenje odnosi na zelenilo } \\
\text { Gradskog parka? }\end{array}$ & $\begin{array}{l}\text { a) Uopće se ne odnosi } \\
\text { b) Ne odnosi se } \\
\text { c) Niti se odnosi niti se ne odnosi } \\
\text { d) Odnosi se } \\
\text { e) Izrazito se odnosi } \\
\text { f) Ne znam }\end{array}$ & $\begin{array}{l}\text { a) } 9 \\
\text { b) } 11 \\
\text { c) } 9 \\
\text { d) } 37 \\
\text { e) } 35 \\
\text { f) } 0\end{array}$ \\
\hline 3. & $\begin{array}{l}\text { Koliko se problem vandalizma } \\
\text { odnosi na zelenilo Gradskog parka? }\end{array}$ & $\begin{array}{l}\text { a) Uopće se ne odnosi } \\
\text { b) Ne odnosi se } \\
\text { c) Niti se odnosi niti se ne odnosi } \\
\text { d) Odnosi se } \\
\text { e) Izrazito se odnosi } \\
\text { f) Ne znam }\end{array}$ & $\begin{array}{l}\text { a) } 0 \\
\text { b) } 0 \\
\text { c) } 0 \\
\text { d) } 35 \\
\text { e) } 65 \\
\text { f) } 0\end{array}$ \\
\hline 4. & $\begin{array}{l}\text { Koliko se problem nedostatka } \\
\text { biciklističke staze odnosi na } \\
\text { zelenilo Gradskog parka? }\end{array}$ & $\begin{array}{l}\text { a) Uopće se ne odnosi } \\
\text { b) Ne odnosi se } \\
\text { c) Niti se odnosi niti se ne odnosi } \\
\text { d) Odnosi se } \\
\text { e) Izrazito se odnosi } \\
\text { f) Ne znam }\end{array}$ & $\begin{array}{l}\text { a) } 0 \\
\text { b) } 4 \\
\text { c) } 2 \\
\text { d) } 26 \\
\text { e) } 67 \\
\text { f) } 0\end{array}$ \\
\hline 5 & $\begin{array}{l}\text { Koliko se problem parkiranja vozila } \\
\text { na zelenim površinama odnosi na } \\
\text { zelenilo Gradskog parka? }\end{array}$ & $\begin{array}{l}\text { a) Uopće se ne odnosi } \\
\text { b) Ne odnosi se } \\
\text { c) Niti se odnosi niti se ne odnosi } \\
\text { d) Odnosi se } \\
\text { e) Izrazito se odnosi } \\
\text { f) Ne znam }\end{array}$ & $\begin{array}{l}\text { a) } 9 \\
\text { b) } 20 \\
\text { c) } 9 \\
\text { d) } 13 \\
\text { e) } 50 \\
\text { f) } 0\end{array}$ \\
\hline
\end{tabular}

- Na pitanje "Koliko se problem nedovoljne osvijetljenosti odnosi na zelenilo Gradskog parka?" većina ispitanika smatra da se to izrazito odnosi (a dovodi se u vezu s pojavom vandalizama i devastacijom stabala i zelenila uopće), dok ih petina percipira da se odnosi (Tablica 3). 
Anarma Poprženović, Špela Pezdevšek Malovrh, B. Dorbić, E. Delić / Stavovi o društvenoj funkciji i općem stanju zelenila u Bihaću (Bosna i Hercegovina) / Glasilo Future (2019) 2 (1-2) 01-14

- U pogledu pitanja o problemu nedostatka klupa za sjedenje i koliko se isto odnosi na zelenilo Gradskoga parka ispitanici su u prosjeku odgovarali da se taj problem odnosi ili izrazito odnosi (trećina ispitanika). Shodno navedenom uvidjelo se tijekom istraživanja da se pojedini posjetitelji tijekom svog boravka u Gradskom parku znaju "odmarati" na travnim površinama i neadekvatno naslanjati na stabla.

- Na postavljeno pitanje koliko se problem vandalizma odnosi na zelenilo Gradskog parka većina se ispitanika izjasnila da se isto izrazito odnosi, a da se ne odnosi smatra manji udio ispitanika. Navedeno ukazuje da je ovo čest problem na urbanoj površini Gradskog parka. Ovakav podatak pokazuje na važnost edukacije djece, adolescenata, odnosno općenito građana o važnosti zelenih površina u gradovima kako bi se podigla svijest građana o tome te se umanjila pojava vandalizma.

- Kako su djeca nesvjesno uništavala urbanu opremu u drugim gradovima, zorno je preslikano iz knjige jednog uglednog šibenskog kroničara: "Šibenska djeca su uglavnom poznavala vremenske intervale kada nije bilo čuvara i njegove šibe, a upravo tada su izvodili različite nestašluke (Belamarić, 2008). U ondašnje vrijeme kako stoji u zabilješkama gospodina Belamarića: "Do 10 sati parkom su šetali težaci, a oko 11 nastupaju činovnici i gospoda. Počinju prometovati perifernom stazom srednjeg đardina. Traje to hodanje dobru uru vrimena, sve uz škripu onog sitnog šljunka $i$ vidno zaprašene postole, a mi i ne vidimo nekog smisla u tom jednoličnom, dosadnom kruženju. Poneki se izdvoje i nastave razgovor na poprečnim stazama, ili kod vaške, gledajući usput crvene ribice. Neki pak, sjednu na klupe. Naposljetku počne osipanje, razilaženje vrijeme je ručka... da bi do 1 sat popodne bilo uspostavljeno normalno stanje i đerdin vraćen nama na raspolaganje" (Belamarić, 2008, prema Dorbić i Temim, 2014).

- Gradski park se nalazi na takvom položaju unutar grada Bihaća da šetnice kroz park čine i prečice za pješake, a i za bicikliste. Uslijed čestih posjeta građana, a i samih prolaznika, građani smatraju da nedostatak biciklističkih staza za bicikliste koji prolaze kroz park predstavlja problem za nesmetano kretanje. Formiranjem biciklističke staze u parku doprinijelo bi i samom uređenju objekta te bi bilo riješeno kretanje pješaka i biciklista. Zanimljivo je navesti i podatak iz istraživanja, prema (Huang, 2006), gdje se navodi da su pješačke staze najslabije snažile društvenu interakciju u odnosu na mjesta u kojima se dulje boravilo u prirodi. Tijekom anketnog istraživanja četvrtina ispitanika se izjasnila da se ovaj problem odnosi na urbano zelenilo parka, dok ih dvije trećine smatra da se izrazito odnosi. Iz danih rezultata može se zaključiti da bi postojanje biciklističke staze kroz park doprinijelo i samom uređenju Gradskog parka, osim toga što bi to bilo korisno za slobodno kretanje pješaka i biciklista (Slika 9.). 
Anarma Poprženović, Špela Pezdevšek Malovrh, B. Dorbić, E. Delić / Stavovi o društvenoj funkciji i općem stanju zelenila u Bihaću (Bosna i Hercegovina) / Glasilo Future (2019) 2 (1-2) 01-14

- Problem parkiranja vozila na zelenim površinama Gradskog parka se prema mišljenju ispitanika ipak odnosi na urbano zelenilo parka. Od ukupnog broja ispitanika, polovica ispitanika smatra da se to izrazito odnosi, a da se ne odnosi smatra petina ispitanika.

U ovom objektu gradskog zelenila problematični su dijelovi prema prometnicama (sjeverni dio) gdje su vidljiva oštećenja od automobilskih guma (dijelovi nagaženih travnjaka, uništeni pokoji tlo pokrivači te oštećeni betonski rubnjaci. Bolja prometna regulacija i postavljanje dodatnih prometnih barijera umanjili bi ovaj problem (Slika 10.).

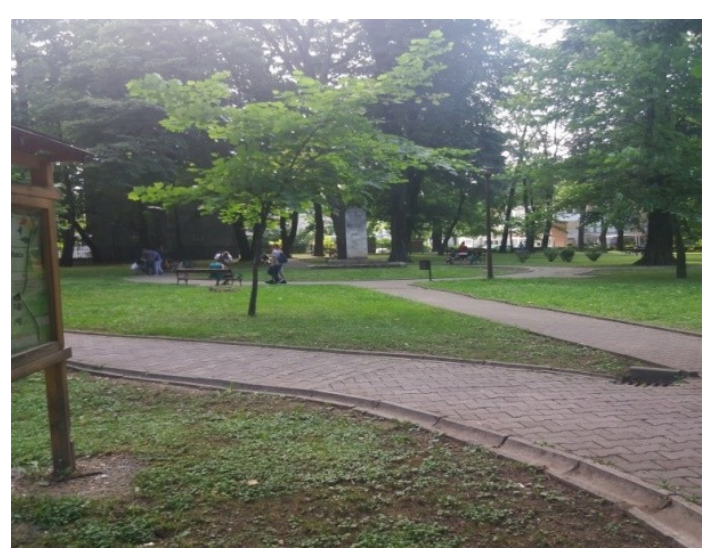

Slika 9. Popločane staze u Gradskom parku (Foto: B. Dorbić, 2018).

Figure 9. Paving paths in the City Park (Photo: B. Dorbić, 2018).

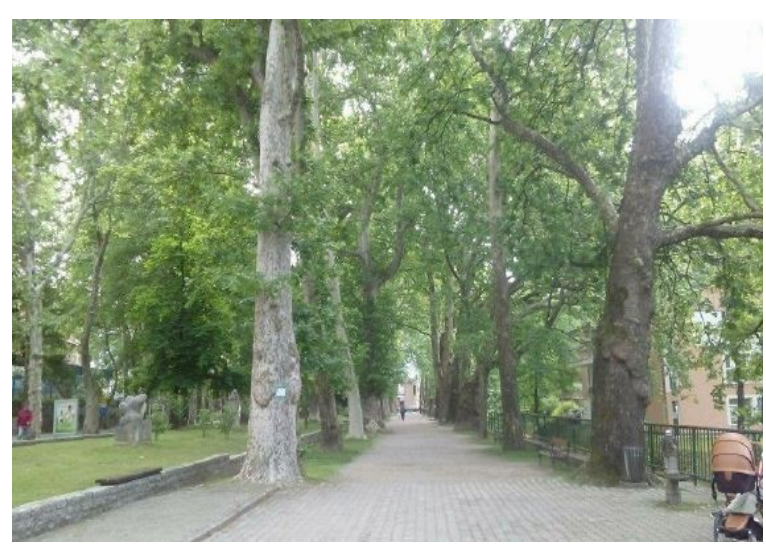

Slika 10. Aleja platana u Gradskom parku (Foto: A. Poprženović, 2018).

Figure 10. Alley plane trees in City Park (Photo: A. Poprženović, 2018).

Ispitanicima je ponuđeno i otvoreno pitanje da se vide postoje li i dodatni problemi u Gradskom parku.

Tablica 4. Dodatni problemi u Gradskom parku prema mišljenju građana/ispitanika (prema Poprženović, 2018).

Table 4. Additional problems in the City Park according to citizens / respondents (according to, Poprženović, 2018).

\begin{tabular}{|l|l|c|}
\hline R. br. & Pitanja & Odgovori (\%) \\
\hline 1 & $\begin{array}{l}\text { U Gradskom parku postoji bespravna gradnja na štetu zelenih } \\
\text { površina }\end{array}$ & 2 \\
\hline 2. & $\begin{array}{l}\text { U Gradskom parku se ne poklanja pažnja bolesnom drveću koje } \\
\text { predstavlja moguću opasnost zaraze za zdrava stabla }\end{array}$ & 4 \\
\hline 3. & U Gradskom parku nedostaje cvijeća i grmlja. & 14 \\
\hline 4. & U Gradskom parku nedostaje javni wc & 4 \\
\hline 5. & U Gradskom parku nema znakova upozorenja za pse & 2 \\
\hline 6. & Gradski park je neosmišljen, neuređen & 72 \\
\hline 7. & Ne znam & 72 \\
\hline
\end{tabular}

- Dodatni problemi u Gradskom parku prema percepciji građana prikazani su u Tablici 4. Velika većina ispitanika (72\%) nije odgovorila na ovo pitanje, dok su se pojedinci izjasnili da se na prvom mjestu nedostataka javlja nedostatak cvijeća (bilo bi poželjno formirati maštovite 
Anarma Poprženović, Špela Pezdevšek Malovrh, B. Dorbić, E. Delić / Stavovi o društvenoj funkciji i općem stanju zelenila u Bihaću (Bosna i Hercegovina) / Glasilo Future (2019) 2 (1-2) 01-14

sezonske cvjetne gredice na ulaznim i centralnim dijelovima) i grmlje (14 \%) (predlažemo uporabu nekih autohtonih vrsta, npr. širokolisna veprina, Ruscus hypoglossum L., mali zimzelen, Vinca minor L. i dr.). Neki od prijedloga posjetitelja su: nedostatka javnog wc-a (4\%), nedostatak znakova upozorenja za pse na zelenim površinama (2\%). Za nedovoljno osmišljen i uređen park se izjasnilo $2 \%$ ispitanika, uočena bespravna gradnja na štetu zelenih površina ( $2 \%$ ). Također, manji broj ispitanika (4\%) smatra da se ne vodi briga o bolesnom drveću koje bi kao takvo proširilo zaraze.

\section{Zaključak}

Temeljem provedenog anketnog istraživanja na temu Stavovi o društvenoj funkciji i općem stanju zelenila u Bihaću došlo se do spoznaja kako slijedi.

Građanima Bihaća Gradski park je najomiljenija zelena površinu u smislu ugode i rekreacije. Polovina ispitanika se u potpunosti slaže da je Bihać "zeleni grad". Zalažu se i za povećanje kvadrature zelenih površina u gradu i daju na značaju edukaciji građana o važnosti zelenih površina.

Analizom stavova o posjećenosti i značaju zelenila Gradskog parka u Bihaću $40 \%$ ispitanika je reklo da Gradski park posjećuje jednom tjedno. Veći broj ispitanika smatra da bi održavanje zelenila Gradskog parka trebali obavljati i sami građani. Prema rezultatima navedenog istraživanja građanima je zelenilo unutar parka izrazito značajno. Smatraju i da postoje problemi koji na neki način štete izgledu parka. Posebno su istaknuli problem loše osvijetljenosti što se dovodi u vezu s pojavom vandalizama i devastacijom stabala. Ispitanici navode i problem nedostatak cvijeća i grmlja u parku te bi bilo poželjno formirati sezonske cvjetne gredice na njegovim ulaznim i centralnim dijelovima.

Postojanje biciklističke staze kroz park doprinijelo bi i samom uređenju parka te bi bilo korisno za slobodno kretanje pješaka i biciklista, a postavljanje dodatnih klupa bi omogućilo duže zadržavanje prolaznika u parku. Uočen je i problem parkiranja vozila na zelenim površinama

Rješenje navedenih problema iziskuje određenu količinu financijskih sredstava, no ukoliko bi se park uredio u skladu s određenim prijedlozima, posjetitelji bi provodili više vremena u njemu te bi i sam park dobio veću vrijednost i veći estetski značaj, a time i opravdao financijska ulaganja.

\section{Zahvala}

Rad je izrađen u okviru izrade Završnog rada Anarme Poprženović, bsc. šumarstva: Vrednovanje urbanog zelenila Gradskog parka u Bihaću. Biotehnički fakultet Univerzitet u Bihaću. Šumarski odsjek. 
Anarma Poprženović, Špela Pezdevšek Malovrh, B. Dorbić, E. Delić / Stavovi o društvenoj funkciji i općem stanju zelenila u Bihaću (Bosna i Hercegovina) / Glasilo Future (2019) 2 (1-2) 01-14

\section{Literatura}

Belamarić, I. (2007). Šibenska sjećanja. Šibenik: Gradska knjižnica "Juraj Šižgorić" Šibenik.

Čaldarović, O. (1989). Društvena dioba prostora. Zagreb: Sociološko društvo Hrvatske.

Delić, E., Medak, J., Bakrač, A., Džafić, S., Dorbić, B., Muhović, B. (2018). Dendroflora Gradskog parka u Bihaću. Glasilo Future 1(3), 01-14.

Dorbić, B., Gaćina, N., Krnčević, M., Krnčević, Ž., Srpak, M. (2012). Krajobrazno uređenje i zaštita ruralnog krajobraza starokršćanske crkve Srima-Prižba kod Šibenika s posebnim osvrtom na gastronomske vrijednosti u svrhu turističke valorizacije. Zbornik radova Međimurskog Veleučilišta u Čakovcu 3(2), 23-31.

Dorbić, B., Gardijan, P., Temim, E., Hadžiabulić, A., Krnčević Rak, M. (2013). Pejzažne karakteristike murve (Morus alba L.) u turističkom identitetu Skradina. Zbornik radova-1. Znanstvenostručna konferencija s međunarodnim sudjelovanjem, Veleučilište u Šibeniku, 515-522.

Dorbić, B., Temim, E. (2014). Utjecaj zelenila i parkovnog modernizma na društveni život stanovnika Šibensko-kninske županije. Agronomski glasnik 76(6), 327-348.

Huang, S.- C. L. (2006). A study in outdoor interactional spaces in high-rise housing. Landscape and Urban Planning, 78, 193-204.

Idžojtić, M. (2009). Dendrologija-List. Zagreb: Sveučilište u Zagrebu. Šumarski fakultet.

Kaplan, R., Kaplan, S. (1989). The experience of nature: A psychological perspective. New York: Cambridge University Press.

Konijnendijk, C. C. (2003). A decade of urban forestry in Europe. Forest Policy Econ. 5(2), 173-186.

Natura Jadera (Javna ustanova za upravljanje zaštićenim dijelovima prirode na području Zadarske županije) (2014). Plan upravljanja "Zelenim otocima" 2015. - 2020. Preuzeto 17. 05. 2016. s mrežne stranice Nature Jadera: http://natura-jadera.com/Dokumenti/plan_upravljanja_zelenim_otocima_20152020.pdf.

Miškić-Domislić, M., Pereković, P., Aničić, B. (2013): Stanovnici o trgovima kao javnim gradskim površinama-Primjer Zagreba, Rijeke i Zadra. Agronomski glasnik 75(4), 209-232.

Poprženović, A. (2018). Vrednovanje urbanog zelenila Gradskog parka u Bihaću. Završni rad. Biotehnički fakultet Univerzitet u Bihaću.

Purcell, L. (2012). Tree Appraisal, Purdue University Department of Forestry \& Natural Resources, 1-8. 
Anarma Poprženović, Špela Pezdevšek Malovrh, B. Dorbić, E. Delić / Stavovi o društvenoj funkciji i općem stanju zelenila u Bihaću (Bosna i Hercegovina) / Glasilo Future (2019) 2 (1-2) 01-14

Radna grupa za izradu projektnog zadatka: Projektni zadatak "Strategija razvoja općine Bihać 2014.2023.", 2014, Razvojni program Ujedinjenih nacija (UNDP) u BiH i Švicarske agencije za razvoj i suradnju (SDC), 108-109.

Ravlić, S. ur. (2019). Likertova ljestvica. Posjećeno 15. 05. 2019, na mrežnoj stranici Hrvatska enciklopedija, mrežno izdanje: http://www.enciklopedija.hr/natuknica.aspx?id=36507.

Seferagić, D. (1988). Kvaliteta života i nova stambena naselja. Zagreb: Sociološko društvo Hrvatske.

Stanić, S., Buzov, I. (2014). Značenje zelenih prostora u životu grada. Godišnjak Titius 6-7 (6-7), 137 153.

Šilić, Č. (1990). Ukrasno drveće i grmlje. Sarajevo: Svjetlost.

Turalija, A. (2005): Mogućnost podizanja drvoreda unutar gradskih aglomeracija. Agronomski glasnik 67(2-4), 99-106.

Tyrväinen, L., Pauleit, S., Klaus, S., de Vries, S. (2005). Benefits and uses of urban forests and trees, 81-114., U: Konijnendijk et al. (2005). Urban forests and trees, 81-114.

Vitasović Kosić, I., Aničić, B. (2005). Istraživanje socioloških aspekata Parka Maksimir. Journal of Central European Agriculture, 6(1), 77-84.

Vršek, I., Kurtela, M. (1995). Razvojna Istraživanja novih vrsta u cvjećarskoj proizvodnji. Sjemenarstvo 12(6), 465-469.

Židovec, V., Karlović, K. (2005). Primjena autohtonog bilja u uređenju gradskog prostora. Agronomski glasnik 67 (2-4), 151-158.

Primljeno: 02. lipnja 2019. godine

Received: Jun 02, 2019

Prihvaćeno: 30 . lipnja 2019. godine

Accepted: Jun 30, 2019 